\title{
Determining the Effects of Institutional Credit on Small Holder Farmer's Productivity: The Case of Tembaro Woreda
}

\author{
Nega Mathewos \\ College of Business and economics, Wolaita Sodo University, Wolaita, Ethiopia
}

\begin{abstract}
The Ethiopian agriculture is characterized by its very low productivity with grain yields. The establishment and expansion of financial service is also one of the instruments to break the vicious circle of poverty-Government of less developed countries has fragmentally practiced the policy of providing cheap credit sector through financial intermediaries. This cheap credit, it was hoped, would lower the dependence on the rural/money lenders. Sufficient credit provision is a serious problem to implant technological advancements and achieve technical efficiency, moreover the establishment and expansion of financial service is also one of the instruments to break the vicious circle of poverty. The objective of this paper was to assess the effects of institutional credit on smallholder farmer's productivity. A total of 120 respondents were used to attain the objective of the study and OLS method was used to analyse the econometric data Results show that age, agricultural credit, education, wealth status and land has significant positive impact on crop productivity. The finding of this research indicates that The productivity of those peoples who were using credit shows a positive change. Various variables were expected to affect small householders' productivity. The variables were age, land, marital status, wealth status, access to credit and educational status. Among the factors the OLS result reveals that all the factors such as age, land, marital status, wealth status, access to credit and educational status were some of the factors which have a positive effect on the small house holder's productivity. The study recommended that Since access to credit has a positive relation with the productivity of small household, the concerned bodies should facilitate credit access to peoples in the area. Education is a base for all things. As the peoples educated more the production and productivity of crops will increase. Therefore, the woreda's administrator and other concerned bodies should focus and give attention to increase the quality of education in the area.
\end{abstract}

Keywords: Credit, Productivity

DOI: $10.7176 / \mathrm{JESD} / 10-21-04$

Publication date: November $30^{\text {th }} 2019$

\section{INTRODUCTION}

\subsection{Background of the Study}

In spite of huge agriculture potential, the growth agriculture production has not been able to keep face with that demand. In fact a high proportion of cultivated land is owned by subsistence farmers who produce about $97 \%$ of national agriculture is output (Wolday, 2006).

The Ethiopian agriculture is characterized by its very low productivity with grain yields reported for various crops varying between 5.1 and 9.6 quintals per hectares over the 1960-1991 periods (Belay, 2008).

The level of poverty in Ethiopia is extensive. The 1995/96 and 1999/00 house income consumption and expenditures survey and welfare monitoring survey of central statistical authority show that about $44 \%$ of the total population, $45 \%$ in rural area and $37 \%$ in urban area living below poverty line (CSA, 2012).

The establishment and expansion of financial service is also one of the instruments to break the vicious circle of poverty-Government of less developed countries has fragmentally practiced the policy of providing cheap credit sector through financial intermediaries. This cheap credit, it was hoped, would lower the dependence on the rural/money lenders (Pinaki, 2009).

\subsection{Statements of the Problem}

Agriculture production is strongly conditional by the fact that inputs are the transformed into outputs with considerable time lags, causing the rural households to balance its budget during the season when there are high expenditure for input purchase and consumption and few revenues. With shortages of access to credit, the budget balance within the year can become a constraint to agriculture production. Thus, if people are unable to finance their agricultural projects themselves, they have to borrow from outside either formal lending institutional or informal money lenders. Winter -Nelson and Temu (2010) stated that small scale farmers in developing countries may become trapped in poverty by lack of the liquidity needed to make profitable investments. Increased access to credit could generate pro-poor economic growth if poor households are gain sufficient credit from financial institutions, otherwise liquidity-constrained households benefit from the new financial services.

In Ethiopia about more than $85 \%$ population is highly engaged in agriculture activities but its production and productivity is very low. This is due to the fact that almost all of the farmers use local technologies and endogenous variety of seeds. To feed the ever growing population small scale farmers should be equipped with science based 
modern agriculture technologies (WB, 2008).

Lack of agriculture credit has become a bottle neck of development of the agriculture sectors. Moreover providing access to credit to small holder farmers can increase their production and productivity. In addition more such opportunities for farmers would result in technological transfer that raises productivity significantly. While producing the necessary technical inputs, if supports other elements in overall developments plans. Therefore if must receive support from other measure relating both to agriculture and other sectors of the economic. To have full effect in promoting increase in output per head of rural population there by stimulates the whole economy (Desale, 2007).

Success to affordable credit is one of the most important factors affecting production and therefore income of the poor. The poor access to agrarian and support services are attributed to socio- economic factors of the farmers as well as constraints encountered by these formers in institution in serving the small scale farmers and the involves high risk and high transaction costs (Okurut, 2004 and Spio, 2002).

At present time micro finance institutions have taken the responsibility of financing and supporting the agriculture sector- micro finance provides credit for small holder farmers though farmer service cooperative for the purpose of purchase of fertilizers, improved seeds and other inputs (Tembaro woreda microfinanceoffice, 2017). However, the question of credit for optimal production increased from time to time. Previous studies that were conducted so far mainly focused on the role and the effect of credit in raising the income at the national level. There is no research work undertaken on the effects of agricultural credit to the overall development of small holder in the study area. Thus, this study fills this gap.

\subsection{Objectives of the Study}

\subsubsection{General Objective}

The general objective of the study was determining the Effects of Institutional Credit on Small Holder Farmer's Productivity in Tembaro Woreda

\subsubsection{Specific Objectives}

The specific objectives of the study were as follows:-

* To assess effects of credit on small holder farmers.

* To analysis the factors that affect productivities of small holder farmers

\section{RESEARCH METHODOLOGY}

\subsection{Description of Study Area}

Tembaro Woreda is located in Kembata Tembaro Zone, SNNPR. It is located at about $400 \mathrm{~km}$ and $180 \mathrm{~km}$ south of Addis Ababa and south west of the principal city of the region Hawassa, respectively. Tembaro district is composed of 20 administrative Kebeles and bordered by Omo River in the south, Hadero and Tunto zuria Woreda in the east, Soro Woreda in the west and Duna Woreda in north. Geographically, it is located between 320 98' E to 340 29'E and $8008^{\prime} \mathrm{N}$ to $809^{\prime} \mathrm{N}$. The total area of the district is about 27,917 hectares. The altitude of the Woreda ranges from 800 to 2600 m.a.s.l and the slope ranges from intermediate (3-30\%) to very steep slope (above30\%) (BoARD, 2007). The study area was encompassed two kebeles namely Bachira and Waro.

\subsection{Sampling Technique and Sample Size}

Two kebeles were selected by using probability proportional to sample of sampling techniques. Bachira and Waro. The total households for both kebele are 2250.As for as sampling techniques concerned, both purposive sampling and simple random sampling procedure were used.

\subsection{Sample Size Determination}

The sample size was determined by Yamane's formula. Then Yamane's sampling formula with 95 percent confidence level used to determine sample respondents.

$$
n=\frac{N}{1+N\left(e^{2}\right)}
$$

Where $\mathrm{n}=$ sample size

where $\mathrm{N}=$ total number of household from two kebeles

where $\mathrm{e}=$ margin of error

Number of households in Bachira Kebele $=950$

Numbers of household in Waro Kebele $=1300$

$\mathrm{N}=950+1300$

$\mathrm{N}=2250$ houholds

Base on this formula 50 households were selected from Bachira Kebele and 70 households were selected from Waro Kebele 


\subsection{Data Source and Method of Data Collection}

Both qualitative and quantitative data were used. Regarding source of data, primary data source was obtained from respondents by using household interview survey and questionnaire. The secondary data were collected from review available literature, books and documents, published and unpublished materials.

\subsection{Data Analysis and Model Specification}

Analysis of data was decisive part of research study. Collected data were presented and analysed descriptively by the help of table and the OLS were specified in this study to analyse effects of institutional credit on smallholder farmer's productivity can be expressed as follows:

Crop Prodn $=\beta \mathrm{o}+\beta 1$ age $+\beta 2$ marstatus $+\beta 3$ edu $+\beta 4$ credit $+\beta 5$ wealthstatus $+\beta 6$ land $+\mu$

\section{RESULTS AND DISCUSIONS}

3.1. The effect of credit on productivity

Table 3.1: the effect of credit taken

\begin{tabular}{|l|c|c|}
\hline Is there a change on productivity after taking credit? & Numbers of respondent & Percentages \\
\hline Yes & 120 & 100 \\
\hline No & 0 & 0 \\
\hline Total & 120 & 100 \\
\hline
\end{tabular}

Source: own survey result, 2019

The survey result in table 3.1 stated that all of the respondents replied that there is a tangible change after taking the credit which plays a great role for the increase of production and productivity. This shows that credit has a tangible positive impact on production and productivity in the area

\subsection{The use of profits obtained from credit}

Table 3.2 the use of profits obtained from credit

\begin{tabular}{|l|c|c|}
\hline The use of profits obtained from credit & Number of respondent & Percentages \\
\hline Able to buy improved seeds & 30 & 25 \\
\hline Able to improve the living standard & 40 & 33.3 \\
\hline Able to build to better house & 10 & 8.3 \\
\hline Able to save more & 20 & 16.7 \\
\hline Able to buy livestock & 20 & 16.7 \\
\hline Total & 120 & 100 \\
\hline
\end{tabular}

Source: own survey result, 2019

The survey result in table 3.2 reveals that from the total respondents the majority of the respondents replied that the use of profits obtained from credit were used to improve the living standard themselves and their families whereas the list number of the respondents which accounts $8.3 \%$ of the respondents were used the profits obtained from credit in order to build to better house.

\subsection{Econometric analyses}

Crop Productivity $=\beta 0+\beta 1$ age $+\beta 2$ marstatus $+\beta 3$ edu $+\beta 4$ credit $+\beta 5$ wealth status $+\beta 6$ land $+\mu$

Table 3.3.summarizes the result of ordinary least square

\begin{tabular}{|l|l|l|l|l|}
\hline Productivity & Coefficient & Std. Err. T & t-test & P-value \\
\hline Age & $.245^{* *}$ & .040 & 3.97 & 0.034 \\
\hline Land size & $2.342^{* * *}$ & 1.965 & 3.84 & 0.000 \\
\hline Marital status & $0.342^{* *}$ & 1.578 & 2.08 & 0.041 \\
\hline Wealth status & $2.542^{* *}$ & 3.730 & -2.55 & 0.013 \\
\hline Access to credit & $3.568^{* *}$ & 1.994 & 2.57 & 0.012 \\
\hline Education status & $4.132^{* * *}$ & 1.286 & 9.11 & 0.000 \\
\hline cons & -3.398 & 1.939 & -1.75 & 0.083 \\
\hline
\end{tabular}

Source: own survey result, 2019

The result in table 3.3.summarizes that the age, land, marital status, wealth status, access to credit and educational status were factors affecting small holders productivity. Among the factors the OLS result reveals that all the factors such as age, land, marital status, wealth status, access to credit and educational status were some of the factors which have a positive effect on the small house holder's productivity. Positive (negative) sign on the explanatory variable coefficient indicates that the higher the values of the variable increase (decrease), the likelihood that a small holder farmer's productivity increases (decreases) and vice versa.

The econometric model result in table revealed that age of the household head is statistically significant at $5 \%$ level, and indicates that as household head age increase by one year, the small holder farmers' productivity increase 
by 0.245 quintal. This was because of the younger household head are economically active age and they are open to accept different technology that can boost productivity of household than their older counterpart.

The econometric variable land size was found to positively and significantly relate with dependent variable at the significant level of $10 \%$. The coefficient of the econometric result of land size indicates that, household heads land increased by 1-hectar the small holder's productivity increased by 2.342 quintals. The reason behind this was those farmers with relatively larger area of land tend to involve more in farming activities than those farmers who have smaller area of land to cultivate.

The econometric variable marital status was positively and statically significant at a significant level of $5 \%$. The coefficient of the variable indicates the married households productivity was more than those of unmarried households by 0.342 quintal per hectare. This indicates that those married households were participating in crop production and become more productive than unmarried households.

Wealth status was positively and statistically significant with the dependent variable at the significant level of $5 \%$. The coefficient value indicates that the crop productivity of wealthier household was more than the poor household productivity by 2.542 quintal per hectare. The possible reason is that the rich household is more productve relative to the poor house hold for crop productivity becouse the rich is the ablity to buy fertilizer, improved seed and other materials which are suitable for crop productivities

Access to credit was positively and statically significant at a significant level of $5 \%$. The coefficient of the model indicates that the productivity of household head who have access to credit was more than 3.568quintal per hectare than those who have no access to credit. This shows that household who had access to credit is more productive compared to households with no access to credit.

Educational status was positively and statistical significant at a significant level of $5 \%$. The coefficient of the model indicates that as the education of the household increases by one grade the crop productivity was increased by 4.132 quintal per hectare. This was because educated household are active, flexible and have ability share experience of farming from different training to change their ways of production system.

\section{CONCLUSIONS AND RECOMMENDATIONS}

\subsection{Conclusions}

The productivity of those peoples who were using credit shows a positive change. Therefore that credit has a tangible positive impact on production and productivity in the area. The use of profits obtained from credit was used to improve the living standard peoples in the area. In general the study revealed that credit users were in better position

Various variables were expected to affect small householders' productivity. The variables were age, land, marital status, wealth status, access to credit and educational status. Among the factors the OLS result reveals that all the factors such as age, land, marital status, wealth status, access to credit and educational status were some of the factors which have a positive effect on the small house holder's productivity. Positive (negative) sign on the explanatory variable coefficient indicates that the higher the values of the variable increase (decrease), the likelihood that a small holder farmer's productivity increases (decreases) and vice versa.

\subsection{Recommendations}

$>$ Since access to credit has a positive relation with the productivity of small household, the concerned bodies should facilitate credit access to peoples in the area.

$>$ Education is a base for all things. As the peoples educated more the production and productivity of crops will increase. Therefore, the woreda`s administrator and other concerned bodies should focus and give attention to increase the quality of education in the area.

\section{Reference}

Belay, 2008. The contribution of MF in CISP interventions Woreda of Eastern Hararge zone of Oromia

BoARD, 2007. Agricultural and Rural Development Planning Section Report. People and Housing Survey Report, Central Statistics Authority, Addis Ababa, Ethiopia

CSA, 2012. Area and Production of Major Crops. Sample Enumeration Survey. Addis Ababa, Ethiopia. Dercon, (2000) micro finance in Africa: is it either the problem or solution world development.

Desale, 2007. Review of the performance of agricultural finance in Ethiopia: Pre-and post-reform periods.

Okurut 2004. Fighting poverty with micro credit: Experience in Bangladesh. The university press limited, Bangladesh

Pinaki, 2009. Alternative financing model for disaster risk redaction South Africa.

Spio 2002. Fighting poverty with micro credit: Experience in Bangladesh. The university press limited, Bangladesh

Tembaro woreda microfinance office, 2017. Provision of credit

Winter-Nelson and Temu, 2010. Impact assessment for micro finance: Theory, experience and better practice. 
World development.

Wolday, 2006. Product development in Ethiopia micro finance industry: Challenges and prospects. A paper presented for $11^{\text {th }}$ annual conference of Ethiopian economy

World Bank report, 2008 .A country states report on poverty. 